\title{
Divergent patterns of matrix metalloproteinase activity during wound healing in ileum and colon of rats
}

\author{
W F Seifert, Th Wobbes, Th Hendriks
}

\begin{abstract}
Background-Uncontrolled and increased extracellular matrix degradation during early anastomotic repair in the intestine may reduce wound strength increasing the risk of anastomotic dehiscence.

Aims-To characterise the metalloproteinases present in intact and anastomosed ileum and colon to study their role in matrix degradation after surgery.

Subjects-Tissue extracts of uninjured, and of anastomosed rat ileum and colon at postoperative days $1,2,3,7$, and 90 , were used.

Methods-Metalloproteinases were identified by gelatin and casein zymography. Aminophenylmercuric acetate (APMA) treatment was used to activate latent metalloproteinases.

Results-Both uninjured ileum and colon contained a 60 and $67 \mathrm{kDa}$ activity, but a 54 and $72 \mathrm{kDa}$ gelatinase was present in ileum only, and a $51 \mathrm{kDa}$ activity in colon only. APMA treatment converted the 60 $\mathrm{kDa}$ protease to 54 and $51 \mathrm{kDa}$ forms and the $72 \mathrm{kDa}$ protease to the $67 \mathrm{kDa}$ form. These gelatinases may correspond to latent and active forms of MMP 1 and MMP 2, respectively. Additional metalloproteinases were observed after anastomotic construction. Both ileum and colon contained 95 and $230 \mathrm{kDa}$ gelatinases, which were converted to 83 and $76 \mathrm{kDa}$ forms by APMA. They may be the latent and active forms of MMP 9, respectively. Gelatinolytic activities of 25 and $28 \mathrm{kDa}$ were only found in anastomosed ileum. Caseinolytic activities were only found in ileum extracts and those were most prominent at day 1, 2, and 3 after surgery. Conclusions-The metalloproteinase pattern in ileum and colon differ considerably suggesting that matrix degradation after anastomotic construction may also vary.

(Gut 1996; 39: 114-119)
\end{abstract}

Department of Surgery, University Hospital Nijmegen,

Nijmegen, the

Netherlands

W F Seifert

Th Wobbes

Th Hendriks

Correspondence to: Dr W F Seifert, University Hospital Nijmegen,

Department of Surgery, PO

Box 9101, 6500 HB

Nijmegen, the Netherlands.

Accepted for publication

13 February 1996
Wound healing in the intestine is an area of ongoing research interest because its failure has potentially devastating consequences. Anastomotic dehiscence remains a major complication of gastrointestinal surgery with concomitant high morbidity and death rates. ${ }^{12}$ The integrity and mechanical strength of the intestinal wall is provided by a structural protein network in the submucosa. This connective tissue layer is largely composed of collagen and the turnover of this extracellular matrix component is therefore of considerable importance for anastomotic strength. ${ }^{34}$ Early anastomotic repair is mediated through close coordination of mesenchymal, epithelial, and endothelial cells, which together with rearrangement, growth, and differentiation are important for the tissue remodelling events during wound repair. These cells have to migrate through the existing connective tissue matrix and they achieve this by enzymatic solubilisation and partly degradation of collagen and other extracellular matrix components. In addition, the presence of protein degrading enzymes is necessary for removal of necrotic tissue. However, matrix degradation, although an intrinsic feature of the repair sequence, may at the same time constitute a hazard to wound strength because it may loosen the matrix that has to anchor the sutures. Identification of the enzymes normally present is a prerequisite for characterising abnormalities that arise - and should possibly be corrected - under adverse conditions. For instance, uncontrolled proteinase activity has been postulated as the mechanism responsible for reduced wound strength after anastomotic construction in an infected area. ${ }^{5}$ While we have shown an increased collagenolytic potential during early repair of anastomoses in the rat intestine, ${ }^{6} 7$ the matrix degrading enzymes present in the intact and anastomosed bowel wall have not yet been characterised.

The matrix metalloproteinases (MMPs) degrade a variety of extracellular matrix components and are considered to be the major enzymes responsible for the remodelling of tissue in a wound area. ${ }^{8} 9$ They include interstitial collagenase (MMP 1), gelatinases (MMP 2 and 9), and stromelysin (MMP 3). Increased MMP activities have been detected in epidermal wounds ${ }^{10}$ and in wound fluids of chronic ulcers. ${ }^{11}$

A sensitive method to identify MMP activity in tissues is by the use of zymography. ${ }^{12-16}$ It is based on the property of MMPs to degrade gelatin or casein gels. The advantage of this method is that both molecular weight and activity of the MMPs can be determined simultaneously: it has been used to characterise the numerous latent and active forms of MMPs in a variety of tissue extracts. ${ }^{10} 1217-19$ In this study we used this technique to analyse the MMP profiles in intact ileum and colon, and in anastomoses at various times after operation. 


\section{Methods}

Operative procedure

Three month old male outbred Wistar/ Cpb:WU rats, weighing 255 (8) g (mean (SD), $n=18$ ), were obtained from our own colony (Nijmegen, the Netherlands). The animals were housed in groups of two in Makrolon type 3 cages. Water and a standard laboratory chow (Diet AM II, Hope Farms, Woerden, the Netherlands) were supplied ad libitum. Body weight was recorded daily. The study was approved by the Animal Ethical Review Committee of the Faculty of Medicine, University of Nijmegen.

After a seven day pre-experimental period the rats were randomly divided into six groups. Three rats per group were used to check the reproducibility of the experiment. The animals in the control group were killed at day 0 to determine proteolytic activity in normal ileum and colon. The animals in the other groups were killed at 1, 2, 3, 7, and 90 days after surgery, respectively, to determine the activities in anastomotic tissue of both ileum and colon.

At the day of operation the rats were anaesthetised by an intraperitoneal injection of sodium pentobarbital $(50 \mathrm{mg} / \mathrm{kg})$. Surgery was performed using a Zeiss operation microscope. The abdominal skin was shaved, disinfected with $70 \% \mathrm{v} / \mathrm{v}$ ethanol, and opened by a median laparotomy of $4 \mathrm{~cm}$. In each animal $1 \mathrm{~cm}$ of both ileum and colon was resected at approximately $15 \mathrm{~cm}$ proximal to the ileal-caecal junction and $3 \mathrm{~cm}$ proximal to the rectal-peritoneal reflection, respectively. An end to end anastomosis was constructed using eight single layer inverting interrupted $8 \times 0$ Ethilon (Ethicon, Norderstedt, Germany) sutures. The first suture was placed at the resection edge, at the side where the intestine is connected to the mesentery. The second ligature was placed at $180^{\circ}$ from the first one. Light tension was put on both sutures using small bulldog type haemostatic clamps resulting in an anterior and posterior anastomosis of equal length. At the anterior side three sutures were placed at $60^{\circ}$ distance. To view the posterior side, the anastomosis was reversed pulling the second ligature behind the ligature at the mesenteric side. Both were put under tension again and the remaining three ligatures were placed at $60^{\circ}$ distance. This way, all sutures were localised within $1 \mathrm{~mm}$ from the resection edge. After completion, the abdomen was closed using a $3 \times 0$ silk suture for the fascia and staples for the skin. The animals were killed by means of an overdose of sodium pentobarbital. A $5 \mathrm{~mm}$ sample containing the suture line was collected including the granulation tissue but also uninjured bowel wall. ${ }^{20}$ Resected segments were opened longitudinally, washed thoroughly with ice cold saline, weighed, and frozen in liquid nitrogen until further processing.

\section{Preparation of tissue extracts}

The resected segments remained frozen in liquid nitrogen during pulverisation in a Braun
Microdismembrator. Approximately $25 \mathrm{mg}$ of the pulverised tissue was suspended in one $\mathrm{ml}$ of $1 \%(\mathrm{v} / \mathrm{v})$ Triton X-100, 0.5 M TRIS-HCl $\mathrm{pH} 7 \cdot 6,0.2 \mathrm{M} \mathrm{NaCl}$, and $10 \mathrm{mM} \mathrm{CaCl}_{2}$ at $4^{\circ} \mathrm{C}$. The suspension was frozen and thawed twice and centrifuged $(40000 \mathrm{~g}$ for 30 minutes at $4^{\circ} \mathrm{C}$ ). The freeze-thaw cycles increased the amount of extracted protein of all samples with a factor 1.2 to 1.5 without activating the latent enzymes towards their active forms. The supernatant was collected and dialysed for 48 hours against an ice cold buffer containing $50 \mathrm{mM}$ TRIS- $\mathrm{HCl} \mathrm{pH} 7 \cdot 6,0.2 \mathrm{M} \mathrm{NaCl}$, $5 \mathrm{mM} \mathrm{CaCl}_{2}$. The protein concentration of the extracts was measured using the bicinchoninic acid reagent. ${ }^{21}$ All extracts were stored at $-80^{\circ} \mathrm{C}$ until needed for zymography. Before zymography part of the extracts was incubated with $1 \mathrm{mM}$-aminophenylmercuric acetate (APMA) at $37^{\circ} \mathrm{C}$ for two hours to activate latent proteinases. The activation of the proteinases in the presence of APMA entails the conversion of the pro-enzyme form to its active lower molecular weight form by autoproteolytic cleavage of a peptide fragment from their amino-terminus. ${ }^{22}$

\section{Zymographic analysis of matrix metalloproteinases}

Gelatin (type A: from porcine skin; Sigma Chemical, St Louis, MO, USA) or casein (Sigma Chemical, St Louis, MO, USA) was added to standard Laemmli 7.5\% (w/v) sodium dodecyl sulphate (SDS)-polyacrylamide mixture ${ }^{23}$ at a final concentration of 1 $\mathrm{mg} / \mathrm{ml}$. The samples were diluted $1: 1$ in sample buffer consisting of $62.5 \mathrm{mM}$ TRIS$\mathrm{HCl}, \mathrm{pH} 6 \cdot 8,10 \%$ glycerol, $2 \%$ SDS, and $0.05 \%$ bromphenol blue. After heating at $60^{\circ} \mathrm{C}$ for 20 minutes the samples ( $4 \mu \mathrm{g}$ of protein per well) were loaded onto a $4 \%$ acrylamide stacking gel on a vertical mini gel (Bio-Rad Laboratories, Richmond, CA, USA). Molecular weight reference standards (Sigma, SDS-6H and SDS 7) were electrophoresed on each gel. The gels were cooled to $48^{\circ} \mathrm{C}$ during electrophoresis. They were run at $15 \mathrm{~mA} / \mathrm{gel}$ while stacking and at $20 \mathrm{~mA} /$ gel during the separating phase until the bromphenol blue dye front had reached the bottom of the gel. The gels containing samples of the colon extracts or extracts of both colon and ileum (see Fig 4) were sometimes run 15 minutes longer to further separate the enzymes. After electrophoresis the gels were washed three times in $2.5 \%$ Triton $\mathrm{X}-100(\mathrm{v} / \mathrm{v})$ for 10 minutes at room temperature. After the gels were rinsed twice in a buffer containing 50 $\mathrm{mM}$ TRIS- $\mathrm{HCl}, 5 \mathrm{mM} \mathrm{CaCl}_{2}, 0 \cdot 1 \%$ Triton X$100, \mathrm{pH} 7 \cdot 8$, they were incubated in the same buffer overnight at $35^{\circ} \mathrm{C}$, stained with $0.1 \%$ Coomassie Brilliant Blue (w/v) in $40 \%$ methanol and $10 \%$ acetic acid for 30 minutes, and destained in the same solution without Coomassie Blue (destaining time 15 minutes, three changes). Proteolytic activities were visualised by clear zones indicating the lysis of gelatin or casein. Presence of true metalloproteinases was confirmed by adding $10 \mathrm{mM}$ 

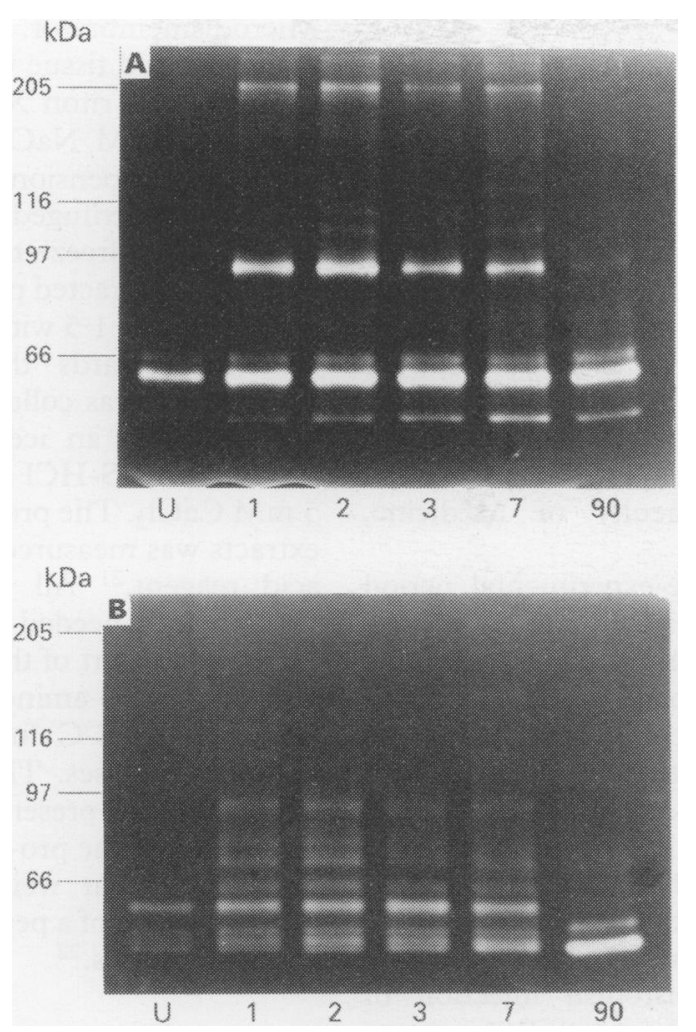

Figure 1: (A) Time course of gelatinolytic activity after

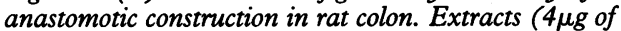
total protein) of uninjured (U) and anastomotic tissue taken at 1, 2, 3, 7, and 90 days after operation were run on a gelatin zymogram. Note the increased activity of the 60 and $51 \mathrm{kDa}$ bands in anastomosed tissue with respect to uninjured colon. The 230 and $95 \mathrm{kDa}$ activities were only present during the first postoperative week (see results). Molecular weight standard markers are shown.

(B) Activation of the colon proMMPs by APMA. The proMMPs of 230,95 , and $60 \mathrm{kDa}$ were partially or totally converted to forms of a lower molecular weight (see results). Molecular weight standard markers are shown.

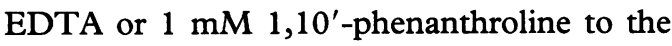
buffers used after electrophoresis.

\section{Results}

At each time point tissue extracts from three rats were available. Figures 1-4 show representative examples of zymography. Each lane shows the activities present in an extract from an individual rat. The pattern of activities was completely reproducible in the other two animals. Reduced staining indicates areas of gelatin or casein degradation and permits identification of, respectively, gelatinase and caseinase activities. The gels containing colon extracts were run 15 minutes longer than those of ileum extract (see methods) to attain a better separation of the 50 to $60 \mathrm{kDa}$ gelatinases. This was possible because colonic extracts did not contain gelatinases with molecular weights lower than $50 \mathrm{kDa}$ (see later).

Several areas of lysis were observed when colonic extracts from both uninjured and anastomotic rat colon were subjected to gelatin zymography (Fig 1A). In uninjured colon, one major activity was present with a molecular mass of $60 \mathrm{kDa}$. Two less prominent bands of 67 and $51 \mathrm{kDa}$ could also be observed. Two additional activities of 95 and $230 \mathrm{kDa}$ were present in colonic anastomoses at one, two, three, and seven days after anastomotic construction. It was also noted that the activity of the 60 and $51 \mathrm{kDa}$ bands was increased with respect to uninjured colon. The activity of the $67 \mathrm{kDa}$ gelatinase did not seem to change at any time after anastomotic construction. At postoperative day 90 , the 95 and $230 \mathrm{kDa}$ bands had disappeared.

After treatment of the same colonic extracts with APMA, the gelatinases were partially or totally converted to forms of a lower molecular size (Fig 1B). Compared with untreated extracts, the $230 \mathrm{kDa}$ band had disappeared and the $95 \mathrm{kDa}$ lysis activity was reduced. New lysis bands of a molecular mass of 83 and 76 $\mathrm{kDa}$ were observed, indicating a precursorproduct relation between the high molecular weight sizes of 230 and $95 \mathrm{kDa}$ and those with lower sizes of 83 and $76 \mathrm{kDa}$. Furthermore, APMA treatment also decreased the activity of the $60 \mathrm{kDa}$ of all colonic extracts. At all time points measured, a new activity was noted at $54 \mathrm{kDa}$ and the intensity of the $51 \mathrm{kDa}$ band increased, particularly at postoperative day 90 .

Both uninjured and anastomotic ileum demonstrated high gelatinase activities at 72 , 67,60 , and $54 \mathrm{kDa}$ (Fig 2A). The $67 \mathrm{kDa}$ band possessed the highest activity and was the most prominent one day after anastomotic construction. A minor band of $95 \mathrm{kDa}$ was detected at postoperative days 1,2 , and 3 . In contrast with colonic extracts, it had already
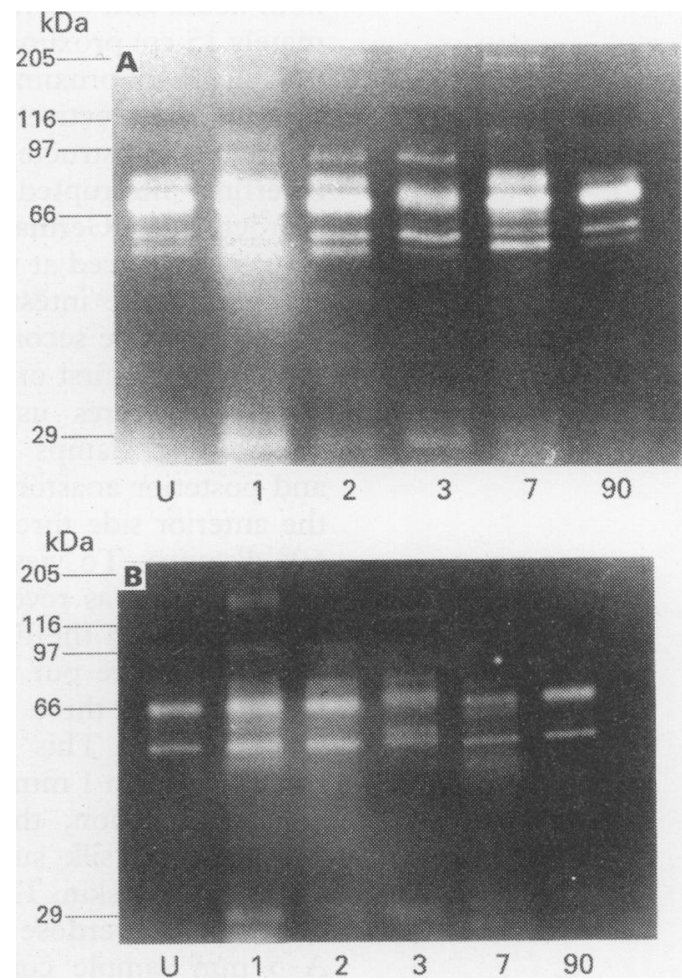

Figure 2: (A) Time course of gelatinolytic activity after anastomotic construction of rat ileum. Ileum extracts (4 $\mu \mathrm{g}$ of total protein) from uninjured ileum (U) and anastomoses taken at one, two, three, seven, and 90 days after operation were run on a gelatin zymogram. With respect to uninjured ileum the 72, 67, 60, and $54 \mathrm{kDa}$ activities were particularly increased at one day after anastomotic construction. Three minor additional activities of 95, 28, and $25 \mathrm{kDa}$ were present at postoperative days 1, 2, and 3 (see results). Molecular weight standard markers are shown. (B) Conversion of the proMMPs in ileal extracts to lower molecular weight forms by APMA. Two major activities of 67 and $54 \mathrm{kDa}$ remained after activation (see results). Molecular weight standard markers are shown. 


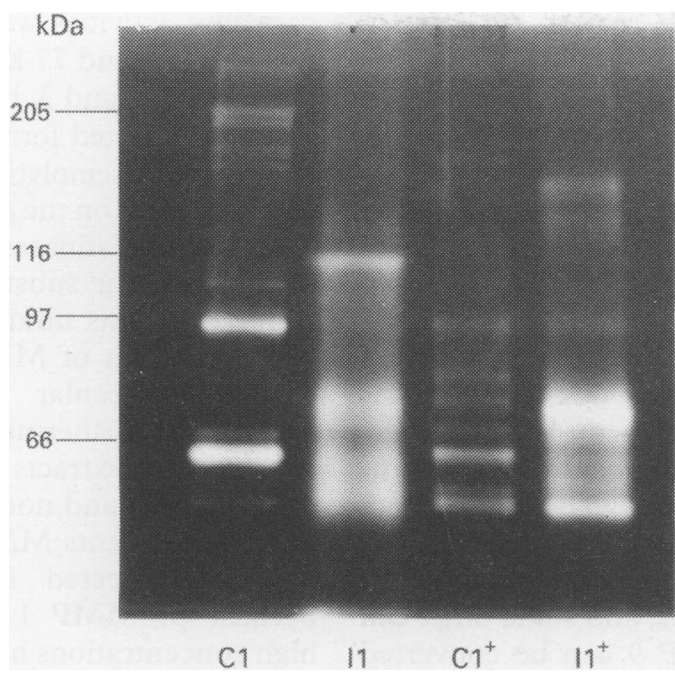

Figure 3: $A$ direct comparison between colonic and ileal anastomoses. Extracts of anastomotic colon (C1) and ileum (I1) at 1 day after surgery; $C 1^{+}$and $11^{+}$after $A P M A$ activation. Note the presence of the $72 \mathrm{kDa}$ activity in ileal extracts and its absence in colonic extracts. The specific enzyme activities on protein basis were higher in ileal extracts than in colonic extracts. Molecular weight standard markers are shown.

disappeared seven days after operation. Extracts of days 1, 2, and 3 also contained two minor activities with a molecular mass of approximately 28 and $25 \mathrm{kDa}$. The bands were not present at days 7 and 90 .

Incubation of the ileum extracts with APMA (Fig 2B) showed two major bands at 67 and 51 $\mathrm{kDa}$, indicating the conversion of the 72 and $60 \mathrm{kDa}$ to lower sizes. In anastomotic tissues at day $1,2,3$, and 7 minor activity was observed at $83 \mathrm{kDa}$. The $95 \mathrm{kDa}$ lysis activity was reduced and the 28 and $25 \mathrm{kDa}$ activities remained unaltered with respect to untreated extracts.

To confirm the apparent differences between ileum and colon, extracts from one day old anastomotic tissue from both bowel parts were run on the same gel (Fig 3). In general, the gelatinase activities in ileum extracts were higher than in colonic extracts. At one day after anastomotic construction ileum extracts included very high activities of gelatinases between 60 and $51 \mathrm{kDa}$ with respect to colonic extracts (Fig 3). Furthermore, very active 72 and $67 \mathrm{kDa}$ bands were present in ileum but not in colon extracts.

Two major bands of lytic activity with molecular masses of 77 and $67 \mathrm{kDa}$ were found when ileum extracts were subject to casein zymography (Fig 4). Both activities increased between one and three days after anastomotic construction but had decreased by seven days after injury. Caseinolytic activity was not observed with colonic extracts (not shown).

Addition of EDTA, as well as 1,10-phenanthroline to the zymography incubation buffer resulted in a complete inhibition of all activities detected in tissues of both ileum and colon.

\section{Discussion}

This study purports to identify the various gelatin and casein degrading metalloproteinases extracted from intestinal tissue before and after anastomotic construction. The results show obvious differences between ileum and colon. Several gelatinases were identified in both uninjured and anastomotic tissue from ileum and colon. Caseinase activity was only present in extracts from ileum. All activities appeared to belong to the metalloproteinase family because EDTA and 1,10phenanthroline were able to inhibit their activity completely. Most of the metalloproteinases were present in the latent form, which could be activated by APMA.

Gelatinase patterns observed in healthy colon and ileum were only partly the same. Both contained a 67 and a $60 \mathrm{kDa}$ gelatinase activity. However, a 72 and $54 \mathrm{kDa}$ gelatinase was present in ileum only, and a $51 \mathrm{kDa}$ activity in colon only. Furthermore, specific gelatinolytic activity in ileal extracts seemed to be higher than in colonic extracts as indicated by the increased intensity of the lysis bands. Previous results on basal collagenolytic activities in uninjured intestine, using fibrillar collagen as a substrate, have also shown a higher activity in ileum than in colon. ${ }^{7}$ These results show that the potential of both tissues to solubilise and degrade collagen or other extracellular matrix components could be different.

Ileum and colon may react differently to injury. Our data show that most of the preexisting gelatinolytic activities were considerably increased in both ileum and colon during the first postoperative days. Raised MMP activities may loosen the extracellular matrix around sutures and thus contribute to the loss of anastomotic strength seen during this period. ${ }^{24}$ In addition, new activities were detected with respect to uninjured intestine. However, the latter seemed more pronounced in colon than in ileum during the first postoperative days and, furthermore, they persisted longer in colonic anastomoses. These results support the hypothesis that localised extracellular matrix degradation in the early postoperative period may be higher in colon than in ileum. ${ }^{25}$ Previous results have also shown that the increase in postoperative collagen synthesis

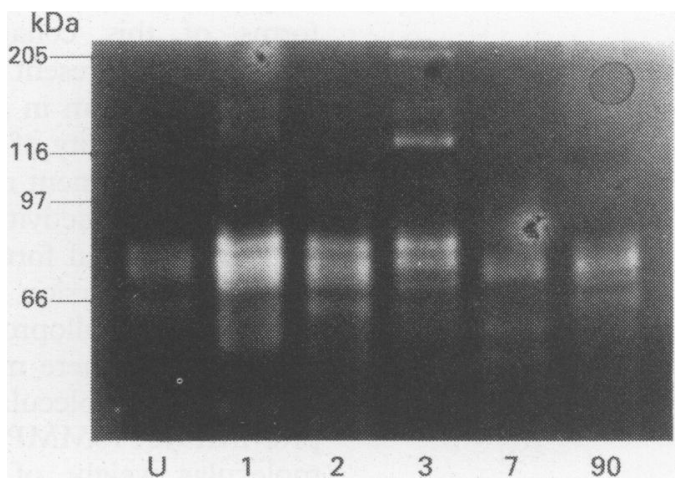

Figure 4: Time course of caseinolytic activity after anastomotic construction in rat ileum. Extracts ( $4 \mu \mathrm{g}$ of total protein) of uninjured $(U)$ and anastomotic tissue taken at one, two, three, seven, and 90 days after operation were run on a casein zymogram. Note the increased activity of the 77 and $67 \mathrm{kDa}$ at postoperative days 1, 2, and 3 (see results). Caseinolytic activity was not observed with colon extracts. Molecular weight standard markers are shown. 
is delayed in colon with respect to ileum. ${ }^{26}$ Together, these findings indicate that the postoperative phase characterised by localised collagen catabolism is possible longer lasting in colon than in ileum. If so, this may be part of the reason why large bowel anastomoses seem to be more prone to leakage than anastomoses in the small bowel. ${ }^{2} 27$

Of the gelatinases found in the tissue extracts, the 95 and $230 \mathrm{kDa}$ gelatinases were induced by anastomotic construction. They may correspond to the propeptide form of the MMP 9 (proMMP 9; 92-95 kDa) (-11 2829 or may represent a multimer of the proMMP 9 (approximately $235 \mathrm{kDa}$ ), respectively..$^{11} 28$ This protease (gelatinase B) is produced by neutrophils, macrophages, and some other cell types. ${ }^{30-32}$ The proMMP 9 can be converted by self cleavage or APMA activation to the active MMP 9 with a molecular mass of 83 $\mathrm{kDa}$. It has also been reported that treatment with excess APMA may result in further cleavage to a $72-76 \mathrm{kDa}$ gelatinase. ${ }^{13}$ Both the 83 $\mathrm{kDa}$ and the $76 \mathrm{kDa}$ form were seen in our APMA treated colon extracts.

In contrast with MMP 9, which was only found in extracts from wound tissue, the other enzyme activities were already present in uninjured intestine, though with a far lesser specific activity. The $67 \mathrm{kDa}$ band was the most prominent activity extracted from ileum, both before and after APMA treatment. This band probably corresponds with the active form of MMP 2.1011 16 Its precursor, proMMP 2 , with a molecular weight of $72 \mathrm{kDa}$ was also present. It has been proposed that MMP 2 (gelatinase A or type IV collagenase) maintains collagen homeostasis in tissues. Wound fibroblasts of rat, but also granulation tissue of skin wounds synthesise MMP 2, ${ }^{1033}$ but inflammatory cells do not.

Zymograms with highly purified preparations of collagenase from human synovial fibroblasts showed that these MMPs have a molecular weight of about $55 \mathrm{kDa}$ (proMMP 1) and 35 $\mathrm{kDa}$ (MMP 1). ${ }^{34}$ Others showed that a porcine MMP of about $52 \mathrm{kDa}$, activated with APMA, was able to degrade collagen. ${ }^{35}$ Our data suggest that ileal and colonic gelatinases in the range of $51-60 \mathrm{kDa}$ may correspond to various forms of this collagenase. Most of these proteases was present in a 60 and 54, and a 60 and $51 \mathrm{kDa}$ form in ileum and colon, respectively. The activity of the $60 \mathrm{kDa}$ was lowered by APMA treatment resulting in an increase of 54 and $51 \mathrm{kDa}$ activities. However, we did not find the activated form of MMP 1 . It may be that the conversion is prevented by tissue inhibitor of metalloproteinases (see later).

Potentially, there may be also other MMPs active with a molecular weight in the range of proMMP 1. ProMMP 3 (pro-stromelysin) has a molecular weight of about $57 \mathrm{kDa}$ and is also very active in gelatin zymograms. ${ }^{34}$ However, when casein, a preferred substrate of (pro)stromelysin, was incorporated into the zymogram gels, no lysis bands of this molecular weight were detected. Thus, uninjured and anastomotic ileum and colon seem not to express stromelysin. On the other hand, two caseinase activities were found with molecular masses of 67 and $77 \mathrm{kDa}$ in ileum at postoperative days 1,2 , and 3 , but not in colon. It may be that the activated forms of MMP 2 and 9 have also a little caseinolytic activity, which could be seen if present on the gel in high concentrations.

Of the gelatinases extracted from ileum detected on the substrate gels, the $25-28 \mathrm{kDa}$ activity remains unidentified. It might be the activated form of MMP 1, although it has a smaller molecular weight than reported earlier. ${ }^{34}$ Furthermore, the activity was expressed in extracts from anastomotic tissue of ileum only and not in extracts of colon. If it indeed represents $M M P 1$, the activity should also be expected in colonic anastomoses because proMMP 1 seems to be present in high concentrations here. Another possibility is that these MMPs correspond to MMP 7 or PUMP-1. ${ }^{8936}$ This member of the MMP family with a molecular weight of $28 \mathrm{kDa}$ has been found in rat uterus. ${ }^{37}$ Whether these intestinal gelatinases participate in extracellular matrix degradation cannot be answered at present. The fact that the activity of these proteases in ileum is higher in anastomotic tissue implies that they may be involved in matrix remodelling.

Gelatin zymography is useful in characterising the activation of most latent metalloproteinases. APMA treatment induced the conversion of $230,95,72$, and $60 \mathrm{kDa}$ forms to lower molecular weight forms. However, the transformation of two of them was incomplete. The 95 and $60 \mathrm{kDa}$ activities still partly exist after three hours of incubation. It has been suggested that some tissue metalloproteinase activity (inter or intramolecular) is needed for a complete transformation. ${ }^{13}$ Also, the addition of exogenous tissue inhibitor of metalloproteinases (TIMP) to culture medium of chondrocytes resulted in the inhibition of most of the APMA induced conversions to lower molecular weights. ${ }^{13}$ It may be that endogenous TIMP is still associated with the proteases in our extracts, and thus limit the effect of the APMA treatment.

The findings of this study show that rat intestine contains MMPs that exist largely in an inactive form. Anastomotic construction increases their presence and additional MMPs are observed. Preliminary results in our laboratory on human rectum and colon showed a MMP pattern similar to that in rat colon suggesting the existence of an interspecies MMP system in the intestine. It remains to be established if patterns of anastomotic MMP activity change under conditions where the development of anastomotic strength is impaired and the risk for anastomotic failure increases. Such studies are currently under way. If this proves to be true, interventions aimed at counteracting activation of specific MMPs may possibly be derived to try to prevent anastomotic insufficiency.

This work was subsidised by Dutch Cancer Society grant NUKC 92-62, Amsterdam.

These data have been published in abstract form at Fourth Annual Meeting of The Wound Healing Society, San Francisco, CA, USA, May 18-20 1994 (Wound Repair and Regeneration 1994; 2: 91). 
1 Turunen M, Peltokallio P. Surgical results in 657 patients with colorectal cancer. Dis Colon Rectum 1983; 26: 606-12

2 Fielding LP, Stewart-Brown S, Blesovsky L, Kearney G. Anastomotic integrity after operation for large bowel cancer: a multicentre study. $B M \mathcal{F} 1980 ; 281$ : $411-4$.

3 Högström H, Haglund U, Zederfeldt B. Suture technique and early breaking strength of intestinal anastomoses and laparotomy wounds. Acta Chir Scand 1985; 151: 441-3.

4 Hendriks T, Mastboom WJB. Healing of experimental intestinal anastomoses. Parameters for repair. Dis Colon Rectum 1990; 33: 891-901.

5 Chowcat NL, Savage FJ, Hembry RM, Boulos PB. Role of collagenase in colonic anastomoses: a reappraisel. $\mathrm{Br} \mathscr{f}$ Surg 1988; 75: 330-4.

6 Van der Stappen JW, Hendriks Th, de Boer HH Collagenolytic activity extracted from intestinal anastomoses of the rat. Matrix 1989; 9: 238-43.

7 Van der Stappen JW, Hendriks Th, de Boer HH, de Man BM, de Pont JJHHM. Collagenolytic activity in experimental intestinal anastomoses. Differences between small and large bowel and evidence for the presence of collagenase. Int $f$ Colorect Dis 1992; 7: 95-101.

8 Matrisian LM. The matrix-degrading metalloproteinases. Bioessays 1992; 14: 455-63.

9 Woessner JF. Matrix metalloproteinases and their inhibitors in connective tissue remodeling. FASEB $\mathcal{f} 1991$; 5 : 2145-54.

10 Ågren MS. Gelatinase activity during wound healing. $\mathrm{Br} \mathcal{f}$ Dermatol 1994; 131: 634-40.

11 Wysocki AB, Staiano-Coico L, Grinnell F. Wound fluid from chronic leg ulcers contains elevated levels of metalloproteinases MMP-2 and MMP-9. F Invest Dermatol 1993; 101: 64-8.

12 Tyagi SC, Matsubara L, Weber KT. Direct extraction and estimation of collagenase(s) activity by zymography in microquantities of rat myocardium and uterus. Clin Biochem 1993; 26: 191-8.

13 Lefebvre V, Peeters-Joris C, Vaes G. Production of gelatindegrading matrix metalloproteinases ('type IV collagenases') and inhibitors by articular chondrocytes during their dedifferentiation by serial subcultures and under stimulation by interleukin-I and tumor necrosis factor $\alpha$. Biochim Biophys Acta 1991; 1094: 8-18.

14 Kleiner DE, Stetler-Stevenson WG. Quantitative zymography: detection of picooram quantities of gelatinases. Anal Biochem 1994; 218: 325-9.

15 John Chen WY, Rogers AA, Lydon MJ. Characterization of biologic properties of wound fluid collected during early stages of wound healing. F Invest Dermatol 1992; 99: stages of

16 Zucker S, Mancuso P, DiMassimo B, Lysik RM, Conner C, Wu C-L. Comparison of techniques for measurement of gelatinases/type IV collagenases: enzyme-linked
immunoassays versus substrate degradation assays. Clin immunoassays versus substrate

17 Tamakoshi K, Kikkawa F, Nawa A, Maeda O, Kawai M, Sugamuma $S$, et al. Different pattern of zymography between human gynecologic normal and malignant tissues. Am F Obstet Gynecol 1994; 171: 478-84.

18 Bendeck MP, Zempo N, Clowes AW, Galardy RE, Reidy MA. Smooth muscle cell migration and matrix metalloproteinases expression after arterial injury in the rat. Circ proteinases $1994 ; 75: 539-45$.
19 Talhouk RS, Chin JR, Unemori EN, Werb Z, Bissell MJ. Proteinases of the mammary gland: development regulation in vivo and vectorial secretion in culture. Development 1991; 112: 439-49.

20 Seifert WF, Wobbes T, Hoogenhout J, de Man BM, Huyben KMLC, Hendriks T. Intraoperative irradiation delays anastomotic repair in rat colon. Am F Surg 1995; 170: 256-61.

21 Smith PK, Krohn RI, Hermanson GT, Mallia AK, Gartner FH, Provenzano MD, et al. Measurement of protein using bicinchoninic acid. Anal Biochem 1985; 150: 76-85.

22 Grant GA, Eisen AZ, Marmer BL, Roswit WT, Goldberg GI. The activation of human skin fibroblast procollagenase: sequence identification of the major conversion products. F Biol Chem 1987; 262: 5886-9.

23 Laemmli UK. Cleavage of structural proteins during the assembly of the head of bacteriophage $\mathrm{T}_{1}$. Nature 1970; 227: 680-5.

24 Jönsson $\mathrm{K}$, Jiborn $\mathrm{H}$, Zederfeldt $\mathrm{B}$. Breaking strength of small intestinal anastomoses. Am f Surg 1983; 145: 800-3.

25 Hendriks Th, Vereecken THLG, Hesp WLEM, Schilling PHM, de Boer HHM. Loss of collagen from experimenta intestinal anastomoses: early events. Exp Mol Pathol 1985; 42: 411-8.

26 Martens MFWC, Hendriks Th. Postoperative changes in collagen synthesis in intestinal anastomoses of the rat. Differences.

27 Hesp WLEM, Lubbers EJC, Hendriks Th, de Boer HHM. Anastomotic insufficiency in small bowel surgery. Langenbecks Arch Chir 1986; 368: 105-11.

28 Goldberg GI, Strongin A, Collier IE, Genrich LT, Marmer $\mathrm{BL}$. Interaction of the $92 \mathrm{kDa}$ type IV collagenase with the inhibitor TIMP prevents dimerization, complex formation with interstitial collegenase and activation of proenzyme with stomelysin. 7 Biol Chem 1992; 267: 4583-91.

29 Lyons JG, Birkedal-Hansen B, Moore WGI, O'Grady RLO, Birkedal-Hansen $\mathrm{H}$. Characteristics of a $95-\mathrm{kDa}$ matrix metalloproteinase produced by mammary carcinoma metalloproteinase produced by mamn
cells. Biochemistry 1991; 30: 1449-56.

30 Hibbs MS, Hasty KA, Seyer JM, Kang AH, Mainardy CL Biochemical and immunological characterization of the secreted forms of human neutrophil gelatinase. $\mathcal{F}$ Biol Chem 1985; 260: 2493-500.

31 Vartio T, Hovi T. Polypeptide composition of human macrophage gelatinase. Acta Chem Scand B 1987; 41: 754-6.

32 Herron GS, Banda MJ, Clark EJ, Gavrilovic J, Werb Z Secretion of metalloproteinases by stimulated capillary endothelial cells. $\mathcal{F}$ Biol Chem 1986; 261: 2814-8.

33 Sakata K, Hoshino K, Nakagawa $H$. Purification and characterization of exudate gelatinases in the chronicphase of carrageenin-induced inflammation in rats. $f$ Biochem 1989; 105: 384-9.

34 Manicourt D-H, Lefebvre V. An assay for matrix metalloproteinases and other proteases acting on proteoglycans,
casein, or gelatin. Anal Biochem 1993;215: 171-9.

35 Ågren MS, Taplin CJ, Woessner JF, Eaglstein WH, Mertz PM. Collegenase in wound healing: effect of wound age and type. F Invest Dermatol 1992; 99: 709-14.

36 Quantin G, Murphy G, Breathnach R. Pump-I DNA codes for a protein with characteristics similar to those of classical collagenase family members. Biochemistry 1989; 28: 5327-34.

37 Woessner JF, Taplin CJ. Purification and properties of a small latent matrix metalloproteinase of the rat uterus. f Biol Chem 1988; 263: 16918-25. 